FITRAH Jurnal Kajian Ilmu-ilmu Keislaman

Vol. 04 No. 1 Juni 2018

e-ISSN : 2460-2345, p-ISSN: 2442-6997

Web: jurnal.iain-padangsidimpuan.ac.id/index.php/F

\title{
MENINGKATKAN HASIL BELAJAR PESERTA DIDIK MELALUI MODEL TADZKIRAH BERBASIS MASALAH DI KELAS VII-7 SMP NEGERI 2 PADANGSIDIMPUAN TAHUN PELAJARAN 2017/2018
}

\author{
MULKEIS \\ Guru SMP Negeri 2 Padangsidimpuan, Ketua MGMP PAIN SMP \\ Kota Padangsidimpuan, Ketua Umum AGPAII Kota Padangsidimpuan \\ mulkeismatondang@yahoo.co.id
}

\begin{abstract}
This research was conducted to determine the improvement of students' learning outcomes in using problem based learning model tazkirah islamic education at class VII- SMP N 2 Padangsidimpuan 2017/2018 and also to determine the improvement of students activeness in using tadzkirah model problem-based. This research found that the improvement of students' outcomes (cognitive) after implementing learning of tadzkirah model problembased in learning islamic education was increased, which is the first score of the students was 68 and the last increses become 81.83. Moreover The increasing of students' activeness and student's attitude was also good, which is in the beginning condition, students was average categorize but in the last cycle, it increased become good categorize.
\end{abstract}

Keywords: Learning Outcomes, Problem based learning models Tazkirah.

\begin{abstract}
Abstrak
Penelitian ini dilaksanakan untuk mengetahui peningkatan hasil belajar peserta didik setelah penerapan model tadzkirah berbasis masalah pada mata pelajaran Pendidikan Agama Islam di Kelas VII-7 SMP Negeri 2 Padangsidimpuan T.P. 2017/2018dan peningkatan keaktifan peserta didik setelah penerapan model tadzkirah berbasis masalah pada mata pelajaran Pendidikan Agama Islam di Kelas VII-7 SMP Negeri 2 Padangsidimpuan T.P. 2017/2018. Dari penelitian yang dilaksanakan diambil kesimpulan: Peningkatan hasil belajar (kognitif) peserta didik setelah penerapan model pembelajaran tadzkirah berbasis masalah pada mata pelajaran Pendidikan Agama Islam di Kelas VII-7 SMP Negeri 2 Padangsidimpuan T.P. 2017/2018adalah pada kondisi awal nilai rata-rata yang diperoleh peserta didik adalah 68, pada akhir siklus kedua meningkat menjadi 81,83 . Peningkatan keaktifan dan akhlak peserta didik dalam pembelajaran setelah penerapan model tadzkirah berbasis masalah pada mata pelajaran Pendidikan Agama Islam di Kelas VII-7 SMP Negeri 2 Padangsidimpuan T.P. 2017/2018 pada kondisi awal berada pada kategori cukup, sedangkan pada akhir siklus kedua meningkat menjadi kategori baik.
\end{abstract}

Kata Kunci : Hasil Belajar, Model Pembelajaran Tadzkirah 
FITRAH Jurnal Kajian Ilmu-ilmu Keislaman

Vol. 04 No. 1 Juni 2018

\section{PENDAHULUAN}

Salah satu tujuan dari penyelenggaraan Pendidikan Agama Islam di Sekolah adalah untuk mencapai hasil belajar yang maksimal, baik dari aspek kognifif, afektif maupun psikomotorik. Terbentuknya akhlak mulia merupakan hasil belajar dari aspek afektif. Namun kenyataan di lapangan saat ini menunjukkan bahwa terjadi kemerosotan akhlak di lingkungan masyarakat saat ini. Hal ini antara lain tampak dari semakin langkanya orang yang berperilaku jujur, amanah dan istiqomah dalam kehidupan sehari-hari. Ketidak jujuran itu antara lain tampak dari tayangan media massa yang menunjukkan semakin banyaknya kasus korupsi, semakin banyaknya orang yang mengkhianati amanah yang diberikan kepadanya, dan semakin banyaknya orang yang tidak istiqomah pada pendirian dan nilai-nilai yang dianutnya.

Kemerosotan akhlak yang terjadi dalam masyarakat dipengaruhi oleh berbagai factor, di antaranya adalah kurangnya pendidikan akhlak yang dilakukan di lingkungan keluarga, sekolah dan masyarakat, krisis keteladanan dan kurangnya pembiasaan akhlak mulia di lingkungan keluarga, sekolah dan masyarakat. Tayangan media massa yang tanpa sensor, sikap dan prilaku pejabat public yang tidak mencerminkan akhlak mulia, kemajuan ilmu pengetahuan dan teknologi yang tidak memiliki kendali iman juga berkontribusi terhadap kemerosotan akhlak yang terjadi saat ini.

Sekolah sebagai lembaga pendidikan formal yang bertugas untuk mendorong berkembangnya potensi peserta didik agar menjadi manusia yang beriman dan bertakwa kepada Tuhan Yang Maha Esa, berakhlak mulia, sehat, berilmu, cakap, kreatif, mandiri, dan menjadi warga negara yang demokratis serta bertanggung jawab (UU No. 20 Tahun 2003 tentang Sistem Pendidikan Nasional Bab II pasal 3), ikut bertanggung jawab terhadap kemerosotan akhlak yang terjadi di tengah-tengah masyarakat. Hal ini disebabkan sekolah merupakan kelanjutan dari pendidikan dalam keluarga yang memiliki tanggung jawab untuk mewujudkan peserta didik yang beriman dan bertakwa serta berakhlak mulia. ${ }^{1}$ Dengan demikian seharusnya salah satu keberhasilan Pendidikan Agama Islam di sekolah dilihat dari terbentuknya peserta didik yang berakhlak mulia. Untuk mewujudkan peserta didik yang berakhlak mulia perlu penerapan strategi, model dan metode pembelajaran yang relevan.

${ }^{1}$ Hasbullah, Dasar-Dasar Ilmu Pendidikan (Jakarta: Raja Grafindo, 2008), hlm. 48. 
Berdasarkan pengalaman penulis dalam melaksanakan pembelajaran Pendidikan Agama Islam di Kelas VII-7 SMP Negeri 2 Padangsidimpuan, pembelajaran yang yang dilaksanakan masih didominasi oleh penggunaan strategi pembelajaran yang lebih berorientasi pada aspek kognitif. Metode yang digunakan masih bercorak menghafal, mekanis, dan lebih mengutamakan pengayaan materi. Peserta didik kurang diberi kesempatan untuk mengembangkan kreativitasnya. Di sisi lain sikap dan prilaku peserta didik belum sepenuhnya menunjukkan pengamalan nilai-nilai ajaran agama Islam, terutama dalam hal pengamalan akhlak mulia. Hal ini antara lain tampak dari masih adanya peserta didik yang tidak jujur ketika menjawab soal ujian, kurang amanah ketika diberikan tanggung jawab, dan kurang istiqomah dalam melakukan sesuatu, padahal salah satu materi pelajaran Pendidikan Agama Islam yang diberikan di Kelas VII SMP adalah jujur, amanah dan istiqomah. Hal ini menunjukkan hasil belajar Pendidikan Agama Islam, terutama pada aspek afektif belum sesuai dengan yang diharapkan.

Untuk meningkatkan hasil belajar peserta didik terutama yang berkaitan dengan akhlak mulia pada mata pelajaran Pendidikan Agama Islam di Kelas VII SMP Negeri 2 Padangsidimpuan, dilakukan berbagai upaya. Salah satu di antaranya adalah dengan menggunakan model pembelajaran yang dapat mendorong peserta didik mengaplikasikan akhlak mulia dalam kehidupan sehari-hari. Salah satu model pembelajaran tersebut adalah adalah model Tadzkirah Berbasis Masalah. Model Pembelajaran tadzkirah berbasis merupakan salah satu model pembelajaran Pendidikan Agama Islam yang dalam pelaksanaannya mengedepankan keteladanan, bimbingan, dorongan, niat tulus, kontinuitas, mengingatkan, pengulangan, mengorganisasikan, dan menyentuh jantung hatinya.

Model Tadzkirah dapat divariasikan dengan model pembelajaran berbasis masalah, yaitu untuk memudahkan peserta didik memahami masalah-masalah yang berkaitan dengan akhlak dalam kehidupan sehari-hari. Dengan demikian proses pembelajaran yang dilaksanakan diharapkan dapat meningkatkan pengetahuan dan pemahaman peserta didik tentang akhlak, dan dapat mengaplikasikannya dalam kehidupan sehari-hari dengan penuh tanggung jawab. Sehubungan dengan hal tersebut penulis tertarik untuk melaksanakan penelitian Tindakan Kelas dengan judul "Meningkatkan Hasil Belajar Peserta 
FITRAH Jurnal Kajian Ilmu-ilmu Keislaman

Vol. 04 No. 1 Juni 2018

didik Melalui Model Tadzkirah Berbasis Masalah di Kelas VII-7 SMP Negeri 2 Padangsidimpuan Tahun Pelajaran 2017/2018".

Berdasarkan latar belakang masalah di atas, maka rumusan masalah dibahas dalam penelitian ini dapat dirinci sebagai berikut:

1. Bagaimanakah peningkatan hasil belajar peserta didik setelah penerapan model tadzkirah berbasis masalah pada mata pelajaran Pendidikan Agama Islam di Kelas VII-7 SMP Negeri 2 Padangsidimpuan T.P. 2017/2018?

2. Bagaimanakah peningkatan keaktifan peserta didik setelah penerapan model tadzkirah berbasis masalah pada mata pelajaran Pendidikan Agama Islam di Kelas VII-7 SMP Negeri 2 Padangsidimpuan T.P. 2017/2018?

\section{MODEL PEMBELAJARAN TADZKIRAH}

Pembelajaran adalah pemberdayaan potensi peserta didik menjadi kompetensi. Kegiatan pemberdayaan ini tidak dapat berhasil tanpa ada orang yang membantu. Dalam Undang-Undang No. 20 Tahun 2003 Tentang Sistem Pendidikan Nasional pasal 1 ayat 20 dinyatakan bahwa pembelajaran adalah proses interaksi peserta didik dengan pendidik dan sumber belajar pada suatu lingkungan belajar.

Menurut Dimyati dan Mudjiono pembelajaran adalah kegiatan guru secara terprogram dalam desain instruksional, untuk membuat belajar secara aktif, yang menekankan pada penyediaan sumber belajar. ${ }^{2}$ Komponenkomponen pembelajaran dikelompokkan dalam tiga kategori utama, yaitu: guru, isi atau materi pembelajaran, dan peserta didi. Interaksi antara tiga komponen utama melibatkan strategi pembelajaran, metode pembelajaran, media pembelajaran, dan penataan lingkungan tempat belajar, sehingga tercipta situasi pembelajaran yang memungkinkan terciptanya tujuan yang telah direncanakan sebelumnya.

Salah satu model pembelajaran yang diterapkan dalam pembelajaran Pendidikan Agama Islam adalah model pembelajaran Tadzkirah. Secara etimologi "Tadzkirah berasal dari bahasa Arab, yaitu kata "dzakkara" yang artinya ingat, dan tadzkirah (dalam bentuk masdar) memiliki arti peringatan. ${ }^{3}$ Dengan demikian model pembelajaran ini mengingatkan peserta didik terhadap tugas dan tanggung jawabnya sebagai manusia sekaligus sebagai hamba Allah

${ }^{2}$ Dimyati dan Mudjiono, Belajar dan Pembelajaran (Jakarta: Rineka Cipta, 2006), hlm. 5.

${ }^{3}$ Dr. Ahmad Zayadi, Abdul Majid, Tadzkirah pembelajaran Pendidikan Agama Islam (PAI) Berdasarkan Pendekatan Kontektual, (Jakarta: Raja Grafindo Perada, 2005), hlm. 42 
Swt. Abdul Madjid dan Dian Andayani merumuskan langkah-langkah tadzkirah sebagai berikut"

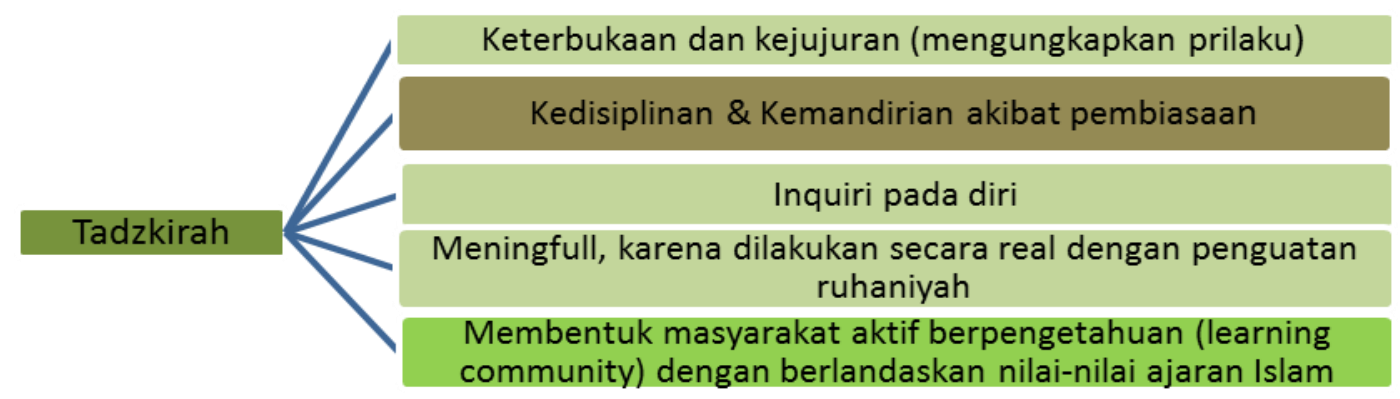

Langkah-langkah tadzkirah yang diuraikan di atas, selanjutnya dikembangkan ke dalam prinsip-prinsip pembelajaran tadzkirah sebagaimana yang diuraikan berikut ini:

\section{Tunjukkan Keteladanan}

Keteladanan merupakan hal yang penting dalam penyelenggaraan Pendidikan Agama Islam. Sifat alami peserta didik yang cenderung meniru sikap dan prilaku orang lain, terutama orang yang dikaguminya menyebabkan keteladanan merupakan hal yang penting dalam menanamkan nilai-nilai ajaran agama Islam dalam kehidupan peserta didik. Dalam kamus besar bahasa Indonesia disebutkan bahwa, "keteladanan" kata dasarnya "teladan" yaitu: "Perbuatan yang patut ditiru dan dicontoh". ${ }^{5}$ Oleh karena itu "keteladanan" adalah hal-hal yang patut ditiru atau dicontoh. Dalam bahasa Arab "keteladanan" diungkapkan dengan kata "uswah" dan "qudwah" yang memiliki arti "pengobatan dan perbaikan". ${ }^{6}$

Menurut Yunus Namsa, keteladanan dalam pendidikan adalah metode influitif yang paling meyakinkan keberhasilannya dalam mempersiapkan dan membentuk moral, spiritual dan sosial anak. ${ }^{7}$ Karena itu pendidik terutama orangtua dan guru merupakan contoh terbaik dalam pandangan anak, yang akan ditirunya dalam tindak tanduknya, dan tata santunnya, disadari atau tidak bahkan terpatri dalam jiwa dan perasaannya, tercermin dalam ucapan

${ }^{4}$ Majid, Abdul, dan Dian Andayani, Pendidikan Karakter Persfektif Islam (Bandung: Remaja Rosda Karya, 2012), hlm. 152.

${ }^{5}$ Hasan Alwi, Kamus Besar Bahasa Indonesia (Jakarta: Balai Pustaka, 2005), hlm. 1160.

${ }^{6}$ Armai Arief, Pengantar Ilmu dan Metodologi Pendidikan Islam, Jakarta: Ciputat Persada, 2002), h. 117.

${ }^{7}$ Yunus Namsa, Metodologi Pengajaran Agama Islam (Jakarta : Pustaka Firdaus, 2000), hlm. 41. 
FITRAH Jurnal Kajian Ilmu-ilmu Keislaman

Vol. 04 No. 1 Juni 2018

dan perbuatan, materil dan spiritual diketahui ataupun tidak diketahui. Selanjutnya Armei Arief menjelaskan untuk menciptakan anak yang saleh, pendidik tidak cukup hanya memberikan prinsip saja, karena yang lebih penting bagi anak adalah figur yang memberikan keteladanan dalam menerapkan prinsip tersebut. Sehingga sebanyak apapun prinsip yang diberikan tanpa disertai contoh teladan, ia hanya akan menjadi kumpulan resep yang tak bermakna. ${ }^{8}$ Menunjukkan keteladanan digunakan untuk merealisasikan tujuan pendidikan Agama dengan memberi contoh keteladanan yang baik kepada peserta didik agar mereka dapat berkembang baik fisik maupun mental dan memiliki akhlak yang baik dan benar. ${ }^{9}$ Dengan demikian keteladanan yang diberikan guru dalam proses pembelajaran merupakan salah satu upaya yang dilakukan dalam mengimplementasikan nilai-nilai ajaran Islam dalam kehidupan sehari-hari.

\section{Arahan (Berikan Bimbingan)}

Bimbingan adalah adalah "petunjuk (penjelasan) cara mengerjakan sesuatu". ${ }^{10}$ Jadi bimbingan adalah suatu proses bantuan yang diberikan kepada seseorang dengan memperkembangkan potensi-potensi yang dimilikinya untuk melakukan sesuatu. Bimbingan merupakan kegiatan yang dilaksanakan secara terus menerus sesuai dengan program yang sudah ditetapkan. Menurut Ahmadi dan Rohani bimbingan berasal dari bahasa Inggris, yaitu "guidance kata dasarnya to guide, yang berarti menuntun, mempedomani, menjadi petunjuk jalan, mengemudikan, dan kemudian diartikan sebagai bimbingan atau bantuan".11 Selajutnya Djumhur menjelaskan bahwa bimbingan adalah "proses bantuan terhadap individu untuk mencapai pemahaman dan pengarahan diri yang diharapkan untuk melakukan penyesuaian diri secara maksimum kepada sekolah, keluarga dan masyarakat".$^{12}$

Sejalan dengan pengertian di atas, Sukardi (1003:21) mengemukakan bimbingan adalah suatu proses bantuan yang diberikan kepada seseorang dengan memperkembangkan potensi-potensi yang dimiliki, mengenali

${ }^{8}$ Armai Arief, Pengantar Ilmu..., hlm. 121.

${ }^{9}$ Armai Arief, Pengantar Ilmu..., hlm. 120.

${ }^{10}$ Hasan Alwi, Kamus Besar... hlm. 367.

${ }^{11} \mathrm{Abu}$ Ahmadi dan Ahmad Rohani, Bimbingan dan Konseling di Sekolah. Jakarta: Rineka Cipta, 1993), hlm. 21.

${ }^{12}$ I. Djumhur dan Moh. Surya, Bimbingan dan Penyuluhan di Sekolah (Bandung: CV Ilmu, 1975), hlm.26. 
dirinya sendiri, mengatasi persoalan-persoalan sehingga mereka dapat menentukan sendiri jalan hidup secara bertanggung jawab tanpa tergantung pada orang lain. Dengan demikian arahan dan bimbingan dalam Pendidikan Agama Islam adalah proses bantuan kepada seseorang dengan tujuan yang jelas, yakni kemandirian, di mana terlebih dahulu pembimbing membawa orang yang dibimbing untuk mengenali dirinya, mengenali potensinya sehingga mampu mengembangkan dirinya serta mampu menghadapi persoalan-persoalan yang dihadapinya dalam kehidupan sehari-hari, sesuai dengan ajaran Islam.

\section{Dorongan (Berikan Motivasi)}

Pemberian motivasi sangat penting dalam proses belajar mengajar. Secara harfiah motif (motive) berarti “alasan, sementara motivasi (Motivasion) berarti pengalasan, daya bathin, dorongan"13 Dari pengertian tersebut dapat dipahami bahwa motivasi adalah daya bathin atau dorongan yang timbul dari dalam diri seseorang. Dalam kamus ilmu dan pendidikan dijelaskan bahwa motif adalah "sebab atau alasan bagi suatu aktivitas"14 selanjutnya Singgih D. Gunarsa Menjelaskan bahwa motif adalah: Dorongan atau kehendak. Jadi yang menyebabkan timbulnya semacam kekuatan agar seseorang itu berbuat atau bertindak, dengan perkataan lain bertingkah laku. Karena tingkah laku tersebut dilatar belakangi oleh adanya motif, maka disebut tingkah laku bermotivasi. $^{15}$ Dari pendapat di atas diketahui bahwa motif adalah daya pendorong yang ada dalam diri seseorang yang menyebabkan ia bertingkah laku. Sedangkan motivasi adalah proses berlangsungnya motif sehingga orangg bertingkah laku.

Cara untuk menumbuhkan motivasi bermacam-macam. Dalam hal ini ada beberapa bentuk dan cara untuk menumbuhkan motivasi dalam kegiatan belajar di di sekolah, di antaranya adalah: "memberi angka, hadiah, saingan/kompetrisi, ego-involvement, memberi ulangan, mengetahui hasil, pujian, hukuman, hasrat untuk belajar, minat. ${ }^{16}$ Upaya yang dilakukan guru hlm. 386.

${ }^{13}$ John M. Echols dan Hasan Shadily, Kamus Inggris Indonesia, (Jakarta: Gramedia, 1982),

${ }^{14}$ A. Murshal M.M. Thaher, Kamus Ilmu Jiwa dan Pendidikan (Bandung: al-Ma'arif, 1977), hlm. 89.

${ }^{15}$ Singgih D. Gunarsa, Pengantar Psikologi (Jakarta: Mutiara, 1983), hlm. 90.

${ }^{16}$ Sardiman, A.M, Interaksi dan Motivasi belajar Mengajar (Jakarta: Rajawali pers, 2000), hlm. 91-94. 
FITRAH Jurnal Kajian Ilmu-ilmu Keislaman

Vol. 04 No. 1 Juni 2018

tersebut diharapkan dapat meningkatkan minat dan motivasi peserta didik belajar Pendidikan Agama Islam.

\section{Zakiyah (Murni atau Bersih, Tanamkan niat tulus)}

Niat belajar bukan hanya sekedar kepentingan duniawi yang selalu dihubungkan dengan status sosial di masa depan, terutama dalam hal pekerjaan dan pendapatan, tetapi juga harus dibarengi dengan kebahagiaan akhirat. Belajar termasuk ibadah bila dikerjakan dengan niat yang murni atau bersih semata-mata karena Allah, berarti kegiatan belajar yang dilaksanakan adalah mencari keridaan Allah agar mendapat derajat yang tinggi, sebagaimana firman Allah Swt. Dalam al-Qur'an surat al-Mujadalah (58:11) berikut ini:

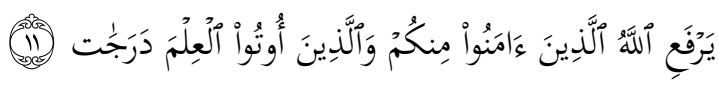

Artinya: ... dan orang-orang yang diberi ilmu beberapa derajat...

Dengan niat yang mulia dan tulus, segala aktivitas belajar dapat diterima oleh Allah sebagai bentuk ibadah kepada-Nya. Niat yang tulus ini akan menumbuhkan motivasi peserta didik mengikuti kegiatan pembelajaran.

\section{Kontinuitas (Pembiasaan)}

Konsep kontinuitas terkait dengan proses pembiasaan dalam belajar. Pembiasaan adalah sebuah cara yang dapat dilakukan untuk membiasakan peserta didik berfikir, bersikap dan bertindak sesuai dengan tuntunan ajaran agama Islam. ${ }^{17}$ Pembiasaan efektif digunakan karena akan melatih kebiasaan kebiasaan yang baik kepada anak sejak dini. Pembiasaan merupakan penanaman kecakapan kecakapan berbuat dan mengucapkan sesuatu, agar cara-cara yang tepat dapat disukai oleh anak. Pembiasaan pada hakikatnya mempunyai implikasi yang lebih mendalam daripada penanaman cara-cara berbuat dan mengucapkan.

\section{Ingatkan}

Dalam proses pembelajaran Pendidikan Agama Islam, guru dituntut untuk selalu mengingatkan kepada peserta didik bahwa mereka diawasi oleh Allah yang mengetahui yang tersembunyi meskipun hanya tersirat di dalam hati, sehingga ia akan senantiasa menjaga perilakunya dari perbuatan tercela. Allah Swt. berfirman dalam al-Qur'an surah al-Asr (103:1-3) sebagai berikut:

${ }^{17}$ Armai Arief, Pengantar Ilmu..., hlm. 110. 


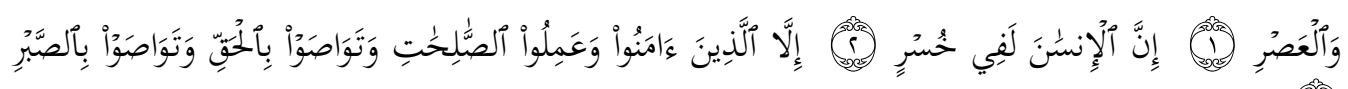

Artinya: Demi masa. Sesungguhnya manusia benar-benar dalam keadaan merugi. Kecuali orang-orang yg senantiasa beriman dan beramal saleh dan saling menasehati di dalam kebenaran dan menasehati dalam kesabaran.

\section{Repetition (Pengulangan)}

Kegiatan pembelajaran perlu dilakukan secara berulang, sehingga mudah dipahami oleh peserta didik. Pengulangan dimaksudkan untuk memastikan bahwa peserta didik memahami persyaratan-persyaratan kemampuan untuk suatu mata pelajaran. Dalam pelajaran agam Islam pengulangn dilakukan agar peserta didik memahami materi pelajaran dan nilai-nilai yang terdapat di dalamnya.

\section{Organisasikan}

Mengorganisasikan pengetahuan dan pengalaman yang sudah diperoleh peserta didik di luar sekolah dengan pengalaman belajar yang diberikannya. Pengorganisasian yang sistematis dapat membantu guru untuk menyampaikan informasi dan mendapatkan informasi secara tepat. Informasi tersebut kemudian dijadikan sebagai umpan balik untu kegiatan belajar yang sedang dilaksanakan.

\section{Heart (Sentuhlah Jantung Hatinya)}

Pada dasarnya Pendidikan Agama Islam adalah pembelajaran spiritualitas, kebersihan hati, ruh, pikiran, jiwa, dan emosi. Strategi pembelajaran tadzkirah menuntut guru harus mampu melaksanakan pembelajaran berdasarkan nilai-nilai spiritual. Di sini guru Pendidikan Agama Islam harus mampu membimbing peserta didik untuk menjadi manusia yang senantiasa beribadah kepada Allah Swt. Menurut Mahmud Arif, konsep ibadah mencakup tri tunggal dimensi, yaitu: 1) dimensi agamawi, 2) dimensi sosial kemasyarakatan, dan 3) dimensi kealaman. Pengenalan Allah sebagai muara akhir pengetahuan manusia dalam bingkai ibadah yang bermakna peneguhan dimensi kemanusiaan manusia dengan segenap potensi fitrah kritis-kreatifnya. ${ }^{18}$ Selanjutnya dalam diri manusia akan muncul kesadaran spiritual (ketuhanan) yang kokoh dan sehat, sehingga

${ }^{18}$ Mahmud Arif, Pendidikan Islam Transformatif (Yogyakarta: LKIS, 2008), hlm. 255. 
FITRAH Jurnal Kajian Ilmu-ilmu Keislaman

Vol. 04 No. 1 Juni 2018

peserta didik mudah menerima kebenaran, dan konsisten dalam melaksanakan ajaran Islam.

\section{PEMBELAJARAN BERBASIS MASALAH}

Pembelajaran Berbasis Masalah merupakan penyajian pembelajaran yang menghadapkan peserta didik pada situasi masalah di dunia nyata yang terjadi di lingkungannya sebelum peserta didik mempelajari materi yang berkenaan dengan masalah yang harus dipecahkan tersebut. Menurut Yatim Riyanto, "dalam pembelajaran berbasis masalah peserta didik dipandang sebagai pribadi yang utuh yang memiliki sejumlah pengetahuan sebagai bekal awal dalam pembelajaran" ${ }^{19}$

Ibrahim dan M. Nur menjelaskan bahwa pembelajaran berbasis masalah "memiliki tujuan untuk membantu peserta didik mengembangkan keterampilan berpikir, pemecahan masalah, belajar berbagai peran orang dewasa dengan melibatkan mereka dalam pengalaman nyata, menjadi pembelajar otonom dan mandiri". ${ }^{20}$

Made Wena menjelaskan bahwa "strategi belajar berbasis masalah merupakan pembelajaran dengan menghadapkan peserta didik pada permasalahan-permasalahan praktis sebagai pijakan dalam belajar atau dengan kata lain peserta didik belajar melalui permasalahan-permasalahan". ${ }^{21}$ Savoie dan Hughes sebagaimana dikutip oleh Made Wena menjelaskan bahwa strategi pembelajaran berbasis masalah memiliki karakteristik, antara lain:

1. Belajar dimulai dengan suatu permasalahan.

2. Permasalahan yang diberikan harus berhubungan dengan dunia nyata peserta didik .

3. Mengorganisasikan pembelajaran di seputar permasalahan, bukan di sekitar disiplin ilmu.

4. Memberikan tanggung jawab yang besar dalam membentuk dan menjalankan secara langsung proses belajar mereka sendiri.

5. Menggunakan kelompok kecil.

19 Yatim Riyanto, Paradigma Baru Pembelajaran, (Jakarta: Kencana Prenada Media Group, 2010), hlm. 284

${ }_{20}$ M. Ibrahim dan M. Nur, Pengajaran Berdasarkan Masalah (Edisi 2). (Surabaya: Unesa University Press, 2005), hlm. 7.

21 Made Wena, Strategi Pembelajaran Inovatif Kontemporer Suatu Tinjauan Konseptual Operasional (Jakarta: Bumi Aksara, 2009), hlm. 91. 
6. Menuntut peserta didik untuk mendemonstrasikan apa yang telah dipelajarinya dalam bentuk produk dan kinerja. ${ }^{22}$

Menurut Wina Sanjaya, model pembelajaran berbasis masalah adalah "rangkaian aktivitas pembelajaran yang menekankan kepada proses penyelesaian masalah yang dihadapi secara ilmiah". ${ }^{23}$ Selanjutnya Wina Sanjaya menjelaskan terdapat tiga ciri utama dari model pembelajaran berbasis masalah, yaitu:

1. Pembelajaran berbasis masalah merupakan rangkaian aktivitas pembelajaran, artinya dalam implementasi pembelajaran berbasis masalah ada sejumlah kegiatan yang harus dilakukan peserta didik . Pembelajaran berbasis masalah tidak mengharapkan peserta didik hanya sekedar mendengarkan, mencatat, kemudian menghafal materi pelajaran, akan tetapi melalu pembelajaran berbasis masalah peserta didik aktif berpikir, berkomunikasi, mencari dan mengolah data dan akhirnya menyimpulkan.

2. Aktivitas pembelajaran diarahkan diarahkan untuk menyelesaikan masalah. Pembelajaran berbasis masalah menempatkan masalah sebagai kata kunci dari proses pembelajaran. Artinya tanpa masalah maka tidak mungkin ada proses pembelajaran.

3. Pemecahan masalah dilakukan dengan menggunakan pendekatan berpikir secara ilmiah. ${ }^{24}$

Sejalan dengan uraian di atas, Ibrahim ${ }^{25}$ menjelaskan dalam pembelajaran berbasis masalah terdapat lima tahap utama, sebagai berikut:

\begin{tabular}{|c|l|}
\hline Tahap & \multicolumn{1}{|c|}{ Tingkah Laku Guru } \\
\hline Tahap1 & Guru menjelaskan tujuan pembelajaran, \\
$\begin{array}{c}\text { Orientasi peserta didik } \\
\text { kepada masalah }\end{array}$ & $\begin{array}{l}\text { menjelaskan logistik yang dibutuhkan, } \\
\text { memotivasi peserta didik terlibat dalam } \\
\text { pemecahan masalah yang dipilihnya. }\end{array}$ \\
\hline
\end{tabular}

22 Made Wena, Strategi Pembelajaran...... hlm.. 91-92.

23 Wina Sanjaya, Strategi Pembelajaran Berorientasi Standar Proses Pendidikan, (Jakarta: Pranada Media Group, 2010) hlm. .

${ }^{24}$ Wina Sanjaya, Strategi Pembelajaran Berorientas...., hlm. 214-215

${ }^{25}$ Wina Sanjaya, Strategi Pembelajaran Berorientas...., hlm. 3-5. 
FITRAH Jurnal Kajian Ilmu-ilmu Keislaman

Vol. 04 No. 1 Juni 2018

\begin{tabular}{|c|l|}
\hline $\begin{array}{c}\text { Tahap 2 } \\
\begin{array}{c}\text { Mengorganisasi peserta didik } \\
\text { untuk belajar }\end{array}\end{array}$ & $\begin{array}{l}\text { Guru membantu peserta didik mendefinisikan } \\
\text { dan mengorganisasikan tugas belajar yang } \\
\text { berhubungan dengan masalah tersebut. }\end{array}$ \\
\hline $\begin{array}{c}\text { Tahap 3 } \\
\text { Membimbing penyelidikan } \\
\text { individual ataupun } \\
\text { kelompok }\end{array}$ & $\begin{array}{l}\text { Guru mendorong peserta didik untuk } \\
\text { mengumpulkan informasi yang sesuai } \\
\text { melaksanakan eksperimen untuk mendapatkan } \\
\text { penjelasan dan pemecahan masalah. }\end{array}$ \\
\hline $\begin{array}{c}\text { Tahap 4 } \\
\text { mengembangkan dan }\end{array}$ & $\begin{array}{l}\text { Guru membantu peserta didik dalam } \\
\text { merencanakan dan menyiapkan karya yang } \\
\text { sesuai seperti laporan, video, dan model serta } \\
\text { membantu mereka untuk berbagi tugas dengan } \\
\text { temannya. }\end{array}$ \\
\hline $\begin{array}{c}\text { Tahap 5 } \\
\text { Menganalisis dan } \\
\text { pemenaluasi proses }\end{array}$ & $\begin{array}{l}\text { Guru membantu peserta didik untuk melakukan } \\
\text { refleksi atau evaluasi terhadap penyelidikan } \\
\text { mereka dan proses-proses yang mereka gunakan. }\end{array}$ \\
\hline
\end{tabular}

Dari uraian di atas dapat dipahami bahwa pembelajaran berbasis masalah adalah interaksi antara stimulus dan respon, merupakan hubungan antara dua arah belajar dan lingkungan yang terdiri dari orientasi peserta didik kepada masalah, mengorganisasikan peserta didik untuk belajar, membimbing penyelidikan individual atau kelompok, mengembangkan dan menyajikan hasil karya, serta menganalisis dan mengevaluasi proses pemecahan masalah.

\section{HASIL BELAJAR PENDIDIKAN AGAMA ISLAM}

Belajar adalah proses perubahan tingkah laku ke arah yang lebih baik melalui pengalaman dan latihan. Seseorang dikatakan belajar jika dapat diasumsikan dalam diri orang itu ada suatu proses kegiatan yang melibatkan suatu proses perubahan tingkah laku. Slameto menjelaskan bahwa: "Belajar adalah proses usaha yang dilakukan individu untuk memperoleh perubahan tingkah laku baru secara keseluruhan sebagai hasil pengalaman individu itu sendiri dalam berinteraksi dengan lingkungannya". ${ }^{26}$ 53.

\footnotetext{
${ }^{26}$ Slameto, Belajar dan Faktor-Faktor Yang Mempengaruhinya (Jakarta: Rineka Cipta, 2002), $1 \mathrm{~m}$
} 
Menurut Rochman Natawidjaya proses belajar adalah proses perubahan tingkah laku individu. Perubahan ini terjadi terus menerus dalam diri individu yang tidak banyak ditentukan oleh faktor keturunan atau genetik. Perubahan karena belajar ini banyak ditentukan oleh faktor-faktor eksternal. Perubahan ini terjadi dalam pengetahuan, keterampilan, sikap, kepribadian, pandangan hidup, persepsi dan motivasi. Tentu saja perubahan ini terjadi sebagai dampak dari pengalaman yang diperoleh dalam situasi khusus. Penyebab terjadinya perubahan itu mungkin dengan sengaja dan sistematis, mungkin meniru perbuatan orang lain atau mungkin juga tanpa sengaja dirancang terlebih dahulu. $^{27}$

Belajar sebagai proses perubahan tingkah laku selanjutnya dijelaskan Winarno Surakhmad yang mengatakan bahwa "belajar adalah proses terjadinya perubahan prilaku melalui pengalaman edukatif". ${ }^{28}$ Selanjutnya Winarno surakhmad menjelaskan bahwa belajar ditujukan kepada: (1) Pengumpulan pengetahuan, (2) Penanaman konsep dan kecakapan, serta (3) Pembentukan sikap dan perbuatan". ${ }^{29}$

Dari uraian di atas dapat dipahami bahwa belajar adalah suatu aktivitas yang menghasilkan perubahan pada individu yang belajar ke arah yang lebih baik melalui pengalaman dan latihan yang bersifat edukatif, dimana perubahan itu bersifat permanen. Artinya perubahan itu tidak berlangsung sesaat saja tetapi dapat bertahan dan berfungsi dalam kurun waktu yang relatif lama.

Hasil belajar dapat diartikan sebagai suatu hasil atau kemampuan seseorang untuk melakukan sesuatu setelah melalui proses belajar, di mana kemampuan tersebut diperoleh karena sebelumnya kemampuan tersebut belum ada pada dirinya. Terjadinya perubahan kemampuan dari belum mampu menjadi mampu menunjukkan adanya hasil belajar. Sementara itu hasil belajar adalah seluruh aspek perubahan sikap dan tingkah laku yang terjadi setelah melakukan aktivitas belajar. Kemampuan-kemampuan tersebut terdiri dari “(1) Hal ihwal keilmuan dan pengetahuan konsep dan fakta (kognitif), (2) Hal ihwal personal, kepribadian dan sikap (afektif), (3) Hal ihwal kelakuan, keterampilan-

${ }^{27}$ Rochman Natawidjaya dan H. A. Moein Moesa, Psikologi Pendidikan (Jakarta: Depdikbud, 2003), hlm. 73.

${ }^{28}$ Winarno Surakhmad, Pengantar Interaksi Belajar Mengajar (Bandung: Tarsito, 1990), hlm. 75.

${ }^{29}$ Winarno Surakhmad, Pengantar Interaksi ...., hlm. 59. 
FITRAH Jurnal Kajian Ilmu-ilmu Keislaman

Vol. 04 No. 1 Juni 2018

keterampilan atau penampilan psikologi" ${ }^{30}$ Sejalan dengan pengertian di atas, Oemar Hamalik menjelaskan "Hasil belajar adalah suatu hasil yang dicapai melalui perbuatan belajar. Hasil yang dicapai berbentuk ranah kognitif (pengetahuan), affektif (sikap) dan psikomotorik (keterampilan)" ${ }^{31}$

Dari uraian di atas dapat dipahami bahwa hasil belajar Pendidikan Agama Islam adalah suatu hasil yang dicapai yang berbentuk ranah kognitif (pengetahuan), affektif (sikap) dan psikomotorik (keterampilan) setelah melaksanakan pembelajaran Pendidikan Agama Islam.

\section{METODE PENELITIAN}

Penelitian ini digolongkan kepada penelitian tindakan dimana penelitian yang dilaksanakan terfokus ke dalam kegiatan di kelas. Dengan demikian jenis penelitian ini merupakan penelitian tindakan kelas. Menurut McNiff "penelitian tindakan merupakan suatu pendekatan untuk meningkatkan pendidikan melalui perubahan dengan mendorong guru untuk menyadari praktek mengajar mereka, kritis terhadap praktek mengajar yang dilakukan, dan siap terhadap perubahan". ${ }^{32}$ Selanjutnya Suharsimi Arikunto menjelaskan bahwa "penelitian tindakan adalah penelitian tentang hal-hal yang terjadi di masyarakat atau kelompok sasaran, dan hasilnya dapat langsung dikenakan pada masyarakat yang bersangkutan". ${ }^{33}$ Jadi penelitian ini termasuk penelitian tindakan, yaitu penelitian tindakan kelas yang dirancang dengan langkah-langkah yang meliputi studi pendahuluan, perencanaan tindakan, pelaksanaan tindakan, observasi dan refleksi.

Penelitian ini dilakukan di SMP Negeri 2 Padangsidimpuan Kota Padangsidimpuan Tahun pelajaran 2017/2018. Penelitian Tindakan kelas ini dilaksanakan pada semester dua Tahun Ajaran 2017/2018, selama kurang lebih 1,5 bulan, yaitu pada bulan September-Oktober 2017. Subjek penelitian ini adalah seluruh peserta didik kelas VIII-7 SMP Negeri 2 Padangsidimpuan Tahun Pelajaran 2017/2018 sebanyak 30 orang.

${ }^{30}$ Sardiman, A.M. Interaksi dan Motivasi belajar Mengajar, (Jakarta: Raja Grafindo Persada, 2000), $\operatorname{lm} 30$.

${ }^{31}$ Oemar Hamalik, Pengembangan Kurikulum (Bandung: Mandar Maju, 1990), hlm. 741.

32 Mc.Niff. J. Action Redearch Principles and Practice (Kent: Makkays of Chatan PLC, 1992), hlm. 4 .

${ }^{33}$ Suharsimi Arikunto, Prosedur Penelitian Suatu Pendekatan Praktek (Jakarta: Rineka Cipta, 2006), hlm. 90. 
Analisis data dilaksanakan secara kualitatif dan kuantitatif. Penelitian Tindakan kelas ini dinyatakan berhasil apabilA: 75\% peserta didik aktif mengikuti kegiatan pembelajaran Pendidikan Agama Islam materi Puasa Ramadhan yang dilaksanakan dan Nilai rata-rata yang diperleh peserta didik minimal 75.

\section{HASIL PENELITIAN DAN PEMBAHASAN}

\section{Kondisi Awal}

Kondisi awal menunjukkan bahwa hasil belajar peserta didik pada mata pelajaran Pendidikan Agama Islam materi jujur, amanah, dan istiqomah di Kelas VII-7 SMP Negeri 2 Padangsidimpuan sebanyak 21,88\% berada pada kategori baik, 18,75\% pada kategori cukup dan 59,37\% berada pada kategori kurang. Dalam hal ini nilai rata-rata yang diperoleh peserta didik pada kondisi awal adalah 68,00. Dari data tersebut dapat diambil kesimpulan bahwa hasil belajar Pendidikan Agama Islam peserta didik pada materi jujur, amanah, dan istiqomah pada pra tindakan berada pada kategori kurang.

Dilihat dari aspek keaktifan peserta didik dalam mengikuti kegiatan pembelajaran juga masih kurang. Hal ini merupakan acuan bagi peneliti untuk menggunakan model pembelajaran tadzkirah dalam kegiatan pembelajaran berikutnya.

\section{Siklus Pertama}

Siklus pertama terdiri dari empat tahap, yakni Perencanaan, Pelaksanaan, Observasi dan Refleksi. Siklus Pertama terdiri dari dua kali pertemuan. Dari kegiatan pembelajaran yang dilaksanakan dapat diketahui bahwa keaktifan peserta didik dalam kegiatan pembelajaran pada siklus pertama adalah perhatian terhadap penjelasan peneliti $9,375 \%$ berada pada kategori sangat aktif, 56,25\% aktif, dan 34,375\% berada pada kategori kurang aktif. Menanggapi pertanyaan peneliti $15,625 \%$ berada pada kategori sangat aktif, 53,125\% aktif dan $31,25 \%$ berada pada kategori kurang aktif. Menanggapi pendapat peserta didik lain 9,375\% berada pada kategori sangat aktif, 59,375\% aktif dan 31,25\% berada pada kategori kurang aktif. Mengajukan pertanyaan 18,75\% berada pada kategori sangat aktif, 46,875\% aktif dan $34,375 \%$ berada pada kategori kurang aktif. Memberikan penjelasan kepada sesama teman $15,625 \%$ berada pada kategori sangat aktif, $46,875 \%$ 
FITRAH Jurnal Kajian Ilmu-ilmu Keislaman

Vol. 04 No. 1 Juni 2018

aktif dan 37,50\% berada pada kategori kurang aktif. Bekerja sama dalam kelompok 15,625\% berada pada kategori sangat aktif, 46,875\% aktif dan $37,50 \%$ berada pada kategori kurang aktif. Mendengarkan penjelasan sebanyak 21,875\% berada pada kategori sangat aktif, 46,875\% aktif dan 31,25\% berada pada kategori kurang aktif. Berdasarkan data tersebut dapat disimpulkan bahwa keaktifan belajar peserta didik pada siklus pertama telah mengalami peningkatan dibandingkan pada kondisi awal.

Pada siklus pertama ini pada tampak bahwa peserta didik sudah terbiasa dengan tadzkirah dan senang mengikuti kegiatan pembelajaran yang dilaksanakan. Dalam hal ini tampak bahwa peserta didik semakin aktif mengikuti kegiatan pembelajaran yang dilaksanakan.

Hasil observasi tentang pengelolaan pembelajaran setelah penerapan sebelum model pembelajaran tadzkirah dilihat dari penerapan langkahlangkah yang sudah ditetapkan dalam pembelajaran. Hasil observasi guru mitra terhadap pengelolaan pembelajaran dengan menggunakan model pembelajaran tadzkirah pada siklus pertama adalah 28 dengan persentase skor yang diperoleh responden $63,64 \%$, yang berarti berada pada kategori cukup. Dengan demikian pengelolaan pembelajaran yang dilaksanakan guru pada siklus pertama masih berada pada kategori cukup.

Setelah selesai proses pembelajaran, maka dilakukan evaluasi untuk mengetahui peningkatan hasil belajar peserta didik pada mata pelajaran Pendidikan Agama Islam setelah penerapan model pembelajaran tadzkirah. Dari Hasil evaluasi diperoleh data tentang hasil Pendidikan Agama Islam peserta didik Kelas VII-7 SMP Negeri 2 Padangsidimpuan pada materi jujur, amanah, dan istiqomah pada siklus pertama diperoleh nilai rata-rata sebesar 74,67. Dengan demikian ada peningkatan yang berarti dibandingkan dengan pra tindakan, yaitu 68. Dari data tersebut dapat diambil kesimpulan bahwa hasil belajar Pendidikan Agama Islam peserta didik pada siklus pertama masih berada pada kategori cukup.

\section{Siklus Kedua}

Siklus kedua terdiri dari empat tahap, yakni Perencanaan, Pelaksanaan, Observasi dan Refleksi yang dilaksanakan selama tiga kali pertemuan. Dalam hal ini dilakukan beberapa revisi terhadap pelaksanaan pembelajaran pada siklus pertama, seperti pemberian reward kepada peserta 
didik yang memiliki hasil belajar dan akhlak paling baik selama berlangsungnya proses pembelajaran. Hasil observasi terhadap keaktifan peserta didik dalam mengikuti kegiatan pembelajaran sesudah menggunakan model pembelajaran tadzkirah pada siklus kedua mengalami peningkatan dibandingkan dengan siklus pertama, yaitu perhatian terhadap penjelasan peneliti 30,00\% berada pada kategori sangat aktif, 60,00\% aktif, dan 10,00\% berada pada kategori kurang aktif. Menanggapi pertanyaan peneliti 40,00\% berada pada kategori sangat aktif, 56,67\% aktif dan 1,33\% berada pada kategori kurang aktif. Menanggapi pendapat peserta didik lain 26,67\% berada pada kategori sangat aktif, 56,67\% aktif dan $16,67 \%$ berada pada kategori kurang aktif. Mengajukan pertanyaan 26,67\% berada pada kategori sangat aktif, 56,67\% aktif dan 6,67\% berada pada kategori kurang aktif. Memberikan penjelasan kepada sesama teman 30,00\% berada pada kategori sangat aktif, $56,67 \%$ aktif dan $6,67 \%$ berada pada kategori kurang aktif. Bekerja sama dalam kelompok 36,67\% berada pada kategori sangat aktif, 56,67\% aktif dan $6,67 \%$ berada pada kategori kurang aktif. Mendengarkan penjelasan sebanyak $60,00 \%$ berada pada kategori sangat aktif, 40,00\% aktif. Berdasarkan data tersebut dapat disimpulkan bahwa keaktifan belajar peserta didik pada siklus kedua mengalami peningkatan dibandingkan pada siklus pertama.

Hasil observasi tentang pengelolaan pembelajaran setelah penerapan sebelum model pembelajaran tadzkirah dilihat dari penerapan langkahlangkah yang sudah ditetapkan dalam pembelajaran. Hasil observasi guru mitra terhadap pengelolaan pembelajaran dengan menggunakan model pembelajaran tadzkirah pada siklus kedua diperoleh skor 45. Dengan demikian persentase skor yang diperoleh responden adalah $80,36 \%$ yang berarti berada pada kategori baik.

Berdasarkan hasil observasi dan evaluasi diketahui bahwa kelebihan dan kelemahan pembelajaran yang terjadi pada siklus pertama adalah sebagai berikut:

a. Guru sudah terbiasa menerapkan model pembelajaran tadzkirah dalam pembelajaran, di mana hasil observasi terhadap aktifitas guru dalam pembelajaran sudah mencapai $80,36 \%$.

b. Peserta didik sudah terbiasa dengan kondisi belajar dengan menggunakan model pembelajaran tadzkirah. Hal ini bisa dilihat dari hasil observasi terhadap aktivitas peserta didik sudah semakin baik. 
FITRAH Jurnal Kajian Ilmu-ilmu Keislaman

Vol. 04 No. 1 Juni 2018

c. Peserta didik aktif dan semakin serius mengikuti kegiatan pembelajaran, termasuk dalam diskusi kelompok dan tanya jawab.

d. Hasil belajar yang diperoleh peserta didik pada akhir siklus kedua sudah mengalami peningkatan yang signifikan dibandingkan dengan siklus sebelumnya, yaitu diperoleh nilai rata-rata sebesar 81,83 .

Dari hasil refleksi di atas, maka diambil keputusan untuk tidak melanjutkan penelitian pada siklus berikutnya karena penelitian yang dilaksanakan sudah mencapai standar keberhasilan yang ditetapkan, yaitu jika $75 \%$ peserta didik aktif mengikuti kegiatan pembelajaran Pendidikan Agama Islam yang dilaksanakan dan nilai rata-rata peserta didik minimal 75. Dalam hal ini nilai rata-rata peserta didik sudah mencapai 81,83 , yang berarti sudah melampaui Kriteria Ketuntasan Minimal yang ditetapkan.

\section{PENUTUP}

\section{Kesimpulan}

Berdasarkan hasil penelitian yang dilaksanakan dapat diambil kesimpulan sebagai berikut:

1. Peningkatan hasil belajar (kognitif) peserta didik setelah penerapan model pembelajaran tadzkirah berbasis masalah pada mata pelajaran Pendidikan Agama Islam di Kelas VII-7 SMP Negeri 2 Padangsidimpuan T.P. 2017/2018 adalah pada kondisi awal nilai rata-rata yang diperoleh peserta didik adalah 68, pada akhir siklus kedua meningkat menjadi 81,83.

3. Peningkatan keaktifan dan akhlak peserta didik dalam pembelajaran setelah penerapan model tadzkirah berbasis masalah pada mata pelajaran Pendidikan Agama Islam di Kelas VII-7 SMP Negeri 2 Padangsidimpuan T.P. 2017/2018 adalah pada kondisi awal berada pada kategori cukup, sedangkan pada akhir siklus kedua meningkat menjadi kategori baik.

\section{Implikasi Hasil Penelitian}

Implikasi darri penelitian ini adalah penerapan model pembelajaran yang bervariasi perlu terus ditingkatkan agar hasil belajar dan keaktifan belajar peserta didik pada mata pelajaran Pendidikan Agama Islam semakin meningkat. Upaya yang dapat dilakukan untuk meningkatkan hasil belajar dan keaktifan belajar peserta didik di antaranya adalah dengan menerapkan model pembelajaran tadzkirah. Dengan penerapan model pembelajaran tadzkirah 
berbasis masalah, motivasi, minat, keaktifan belajar dan kemampuan memecahkan masalah peserta didik semakin meningkat, sehingga hasil belajar yang diperolehnya juga semakin meningkat pula.

\section{Saran-Saran}

Sesuai dengan hasil penelitian, maka penulis mengajukan saran-saran sebagai berikut:

1. Disarankan kepada para guru, khususnya guru-guru Pendidikan Agama Islam untuk menerapkan model pembelajaran tadzkirah agar hasil belajar dan keaktifan belajar peserta didik semakin meningkat.

2. Disarankan kepada instansi terkait, khususnya Dinas Pendidikan dan Kebudayaan dan Kementerian Agama untuk melakukan berbagai kegiatan yang dapat meningkatkan kemampuan guru menerapkan model pembelajaran agar kualitas pembelajaran Pendidikan Agama Islam semakin meningkat. 
FITRAH Jurnal Kajian Ilmu-ilmu Keislaman

Vol. 04 No. 1 Juni 2018

\section{DAFTAR PUSTAKA}

A. Murshal M.M. Thaher. Kamus Ilmu Jiwa dan Pendidikan. Bandung: al-Ma'arif, 1977.

Abdul Majid, dan Dian Andayani. Pendidikan Karakter Persfektif Islam. Bandung: Remaja Rosda Karya, 2012.

Abu Ahmadi dan Ahmad Rohani. Bimbingan dan Konseling di Sekolah. Jakarta: Rineka Cipta, 1993.

Ahmad Zayadi, Abdul Majid, Tadzkirah pembelajaran Pendidikan Agama Islam (PAI) Berdasarkan Pendekatan Kontektual. Jakarta: Raja Grafindo Perada, 2005.

Armai Arief. Pengantar Ilmu dan Metodologi Pendidikan Islam. Jakarta: Ciputat Persada, 2002.

Dimyati dan Mudjiono. Belajar dan Pembelajaran. Jakarta: Rineka Cipta, 2006.

Djumhur, I dan Moh. Surya. Bimbingan dan Penyuluhan di Sekolah. Bandung: CV Ilmu, 1975.

Echols John M. dan Hasan Shadily. Kamus Inggris Indonesia. Jakarta: Gramedia, 1982.

Hasan Alwi. Kamus Besar Bahasa Indonesia. Jakarta: Balai Pustaka, 2005.

Hasbullah. Dasar-Dasar Ilmu Pendidikan. Jakarta: Raja Grafindo, 2008.

M. Ibrahim dan M. Nur. Pengajaran Berdasarkan Masalah (Edisi 2). Surabaya: Unesa University Press, 2005.

Made Wena. Strategi Pembelajaran Inovatif Kontemporer Suatu Tinjauan Konseptual Operasional. Jakarta: Bumi Aksara, 2009.

Mahmud Arif. Pendidikan Islam Transformatif. Yogyakarta: LKIS, 2008.

Mc.Niff. J. Action Redearch Principles and Practice. Kent: Makkays of Chatan PLC, 1992.

Oemar Hamalik. Pengembangan Kurikulum. Bandung: Mandar Maju, 1990.

Rochman Natawidjaya dan H. A. Moein Moesa. Psikologi Pendidikan. Jakarta: Depdikbud, 2003. 
Sardiman, A.M. Interaksi dan Motivasi belajar Mengajar. Jakarta: Raja Grafindo Persada, 2000.

Singgih D. Gunarsa. Pengantar Psikologi. Jakarta: Mutiara, 1983.

Slameto. Belajar dan Faktor-Faktor Yang Mempengaruhinya. Jakarta: Rineka Cipta, 2002.

Suharsimi Arikunto. Prosedur Penelitian Suatu Pendekatan Praktek. Jakarta: Rineka Cipta. 2006.

Winarno Surakhmad. Penganta Interaksi Belajar Mengajar. Bandung: Tarsito, 1990.

Yatim Riyanto. Paradigma Baru Pembelajaran. Jakarta: Kencana Prenada Media Group, 2010.

Yunus Namsa. Metodologi Pengajaran Agama Islam. Jakarta : Pustaka Firdaus, 2000. 
FITRAH Jurnal Kajian Ilmu-ilmu Keislaman

Vol. 04 No. 1 Juni 2018

\title{
PENDIDIKAN KARAKTER MENURUT KH. HASYIM ASY'ARI \\ ( Perspektif Filosofis )
}

\author{
AMIN NURBAEDI \\ Pengawas Pendidikan Agama Islam Yang Juga Mahasiswa Program \\ Pascasarjana (S.3) UNU Surakarta
}

